[8]. J. Lions, "Matrix reduction using the Hungarian method for the generation of school timetables", Communications of the ACM, vol. 9, no. 5, pp. 349-354, 1966. DOI:10.1145/355592.365637.

[9]. A. Dandashi and M. Al-Mouhamed, "Graph Coloring for class scheduling", ACS/IEEE International Conference on Computer Systems and Applications - AICCSA 2010, 2010. DOI:10.1109/aiccsa.2010.5586963.

[10]. Y. Wang, Y. Cheng, T. Chang and S. Jen, "On the application of data mining technique and genetic algorithm to an automatic course scheduling system", 2008 IEEE Conference on Cybernetics and Intelligent Systems, 2008. DOI:10.1109/iccis.2008.4670852.

[11]. T. Islam, Z. Shahriar, M. Perves and M. Hasan, "University Timetable Generator Using Tabu Search", Journal of Computer and Communications, vol. 04, no. 16, pp. 28-37, 2016. DOI:10.4236/jcc.2016.416003.

[12]. D. Li, J. Shen, H. Dong, Y. Su and Z. Zhang, "Application of Genetic Algorithm and Simulated Annealing Algorithm for Course Scheduling Problem", Proceedings of the 2019 International Conference on Modeling, Analysis, Simulation Technologies and Applications (MASTA 2019), 2019. DOI:10.2991/masta-19.2019.69.

[13]. M. Basu, "Hopfield neural networks for optimal scheduling of fixed head hydrothermal power systems", Electric Power Systems Research, vol. 64, no. 1, pp. 11-15, 2003. DOI:10.1016/s0378-7796(02)00118-9.

[14]. M. Aldasht, M. Alsaheb, S. Adi and M. Qopita, "University Course Scheduling Using Evolutionary Algorithms", 2009 Fourth International Multi-Conference on Computing in the Global Information Technology, 2009. DOI:10.1109/iccgi.2009.15.

[15]. O.M. Boiko, "Evoliutsiina tekhnolohiia rozv’yazuvannia zadachi skladannia rozkladiv navchalnykh zaniat", Yskusstvennyy yntellekt, № 3, s. 341-348, 2006. [Elektronnyi resurs]. Rezhym dostupu: http://iai.dn.ua/public/JournalAI_2006_3/Razdel5/01_Boyko.pdf. [Data zvernennia: Kvi. 25. 2021].

[16]. V.A. Turchyna, D.O. Tanasiienko, "Zastosuvannia henetychnoho alhorytmu do zadachi skladannia navchalnoho rozkladu", Pytannia prykladnoi matematyky ta matematychnoho modeliuvannia, t. 18, s. 196-201, 2018. DOI:10.15421/321820.

[17]. A. Colorni, M. Dorigo, V. Maniezzo, "Colorni, Alberto, Marco Dorigo, and Vittorio Maniezzo. "A genetic algorithm to solve the timetable problem", Politecnico di Milano, s. 1-24, 1992. DOI:10.15421/321820. [Online]. Available: https://www.academia.edu/download/33105221/download.pdf. [Accessed: Apr. 25. 2021].

\title{
ТЕОРЕТИЧНІ ТА ПРАКТИЧНІ АСПЕКТИ РОЗРОБКИ ДОДАТКУ-ПОМІЧНИКА ДЛЯ СМАРТФОНІВ
}

\author{
Корніснко Ю. К. ${ }^{1}$, Франциан В. В. ${ }^{2}$ \\ 1,2 Одеська національна академія харчових технологій \\ ORCID: ${ }^{10000-0002-3806-4494 ~}$ \\ E-mail: 1 yurikkorn@gmail.com
}

Copyright (C) 2021 by author and the journal “Automation of technological and business - processes”. This work is licensed under the Creative Commons Attribution International License (CC BY). http://creativecommons.org/licanses/by/4.0
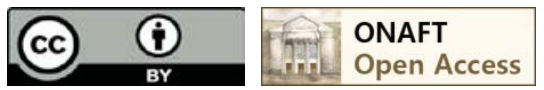

DOI:

Анотація. У перехідних умовах реформації інноваційно-інформаційної економіки, глобальної гіперконкуренції на аграрних ринках, зростання обізнаності й очікувань споживачів щзодо асортименту та якості продукції, особливо актуальним є використання украӥнськими фермерами комплексу доступних інформаційних технологій та новацій. Одним з найбільш перспективних на сьогодні є ринок мобільних додатків, який характеризується активним розвитком. У поєднанні з бездротовими мережами вони мають значний потенціал розширення часу, місия $i$ ефективності виконання робіт аграріями. Разом з тим мобільні технології відкривають нові канали зв'язку $i$ можливості для введення аграрного бізнесу, потенційно пропонуючи більш широкий доступ до суспільної інформації $і$ основних послуг. Метою дослідження є створення програмного продукту, який допоможе в майбутньому у вирішенні проблем, пов'язаних з надлишковою витратою часу на відстеження виконаних завдань та спрощенні изього процесу, а також проведення аналізу ефективності виконання роботи після впровадження ПП. Об'єктом дослідження є удосконалення бізнес-прочесів і оптимізація стандартних дій. Методами дослідження було обрано аналіз оцінювання та вибір потрібної інформації виходячи з переглянутого та порівняння - порівняння двох або більше 
аналогічних підходів або тільки їх окремих складових для отримання потрібної інформації. В результаті проведених досліджень було створено мобільний додаток з голосовим асистентом для двох операційних систем: Android та iOS, щзо дозволяє вести облік виконаних завдань для великих та малих компаній та фізичних осіб.

Abstract. In the transitional conditions of the reform of innovation and information economy, global hypercompetition in agricultural markets, growing awareness and expectations of consumers about the range and quality of products, especially relevant is the use of Ukrainian farmers a set of available information technology and innovation. One of the most promising today is the market for mobile applications, which is characterized by active development. In combination with wireless networks, they have significant potential to expand the time, space and efficiency of farmers. At the same time, mobile technologies open up new communication channels and opportunities for the introduction of agribusiness, potentially offering wider access to public information and basic services. The purpose of the study is to create a software product that will assist in the future in solving problems related to excessive time spent on tracking completed tasks and simplifying this process, and also analyzing the performance of work after the implementation of PP. The object of the study is to improve business processes and optimize standard actions.The methods of the study were chosen to analyze - to evaluate and select the information needed based on the revised, and to compare - to compare two or more similar approaches, or only their separate components, to obtain the required information. As a result of the research, a mobile app with a voice assistant was created for two operating systems: Android and iOS, allowing to keep track of completed tasks for large and small companies and individuals.

Ключові слова: інформаційні технології, голосовий асистент, база даних, OC Android, OC iOS, бiзнес-процеси, тестування програмного забезпечення

Keywords: information technology, voice assistant, database, Android OS, iOS OS, business processes, software testing

Вступ

Світ праці формується переважно міжособистісними взаємодіями, зв'язками та стосунками [1]. Спілкування 3 іншими [2], отримання зворотного зв'язку [3] та формування мереж та дружби - це деякі приклади, які стали натхненними та вирішальними у сучасних робочих контекстах [4]. Відповідно до цих тенденцій, дослідники наголошували на реляційних розробках робочих місць та, зокрема, реляційних роботах (RJC) [5], як на ініціативній поведінці, завдяки якій працівники можуть змінювати своє соціальне середовище та розширюватись. або укласти контракт на взаємодію, щоб ефективно завершити свою роботу.

\section{Теоретичні аспекти}

Незважаючи на визнання, що розробка робочих місць не відбувається у вакуумі, реляційні аспекти крафтової роботи були проігноровані в дослідженнях на сьогодні [7]. Щоб підкреслити, що працівники можуть змінювати своє соціальне середовище через розширення або контрактування своїх реляційних мереж на роботі та сприяти зростанню досліджень реляційних дизайнів роботи [1], було зосереджено увагу на RJC. Відповідно, основна мета цього дослідження полягає у дослідженні механізмів та граничних умов, завдяки яким RJC, орієнтована на розширення та стиснення, впливає на результати праці, а саме, на результативність роботи. Роботу впроваджено як механізм, а мотиви працівників (просоціальні мотиви та управління враженнями) як граничні умови для вивчення наших цілей дослідження.

RJC - форма поведінки, яка займається розробкою роботи, що стосується прояву розсуду, щодо якого людина взаємодіє під час виконання роботи [8]. RJC можна розглядати як спосіб розширення (тобто, орієнтованого на розширення RCJ), так і укладання договору (тобто, RJC, орієнтованого на скорочення) типу, кількості та значення взаємодій, які співробітники мають з колегами на роботі. Приклади RJC, орієнтованого на розширення, можуть включати фокус розмов, що розширюють розмови та проводять зустрічі з новими колегами 3 іншого підрозділу для досягнення робочих цілей або залучення нових колег до проекту. Приклади контракту, орієнтованого на його скорочення, можуть включати обмеження зустрічі з колегою щодо проекту або зменшують конференц-дзвінки 3 колегами, які можуть не брати безпосередньої участі у відповідному проекті.

Дослідження з розробки робочих місць підкреслили, що RJC не потребує і не завжди може мати позитивні результати для організації або працівників. Однак маються на увазі відмітні механізми та наслідки розширення та орієнтованого на скорочення RJC, які не досліджені [9]. Інтегруючи два типи RJC, це дослідження стосується питання "чи існує темна сторона RJC". Це сприяє дослідженню кращого робочого місця, обговорюючи, чи можуть і як співробітники збільшувати чи зменшувати ступінь складності спілкування у їхньому реляційному робочому середовищі, що може позитивно, а також негативно впливати на їхню роботу та результати роботи [5]. Фокус на двох типах RJC також сприяє нещодавньому дослідженню, яке розпочало концептуалізацію крадіжок, орієнтованих на ухилення від роботи (наприклад, виведення робочих місць, схожих на RJC, орієнтовані на скорочення) та демонстрацію негативних наслідків для роботи працівників, які стосуються працівника (тобто ефективність роботи) та організація (тобто організаційна прихильність; [10]). Як результати праці працівників, було зосереджено увагу на оцінці ефективності роботи, щоб дослідити, чи стосуються наслідки розробки роботи не лише основного працівника за рахунок підвищення ефективності роботи, але й організації, що заохочує співробітників, які працюють в центрі уваги, виходять конструктивні пропозиції та дискреційні ідеї, орієнтовані на зміни [11].

Друга недосліджена область у дослідженні крадіжки на роботі стосується типів працівників, які з більшою чи меншою ймовірністю займаються та перекладають вплив на роботу, а також в контексті дослідження, орієнтованого 
на розширення та стиснення RJC, на результати роботи. I розширення, і скорочення RJC відбуваються на рівні людини [12]. Таким чином, були інтегровані мотиви просоціального управління та управління враженнями працівників, щоб дослідити, до яких характеристик працівника пов'язувати, та пояснити, для кого RJC перетворюється на посилену робочу активність із наступним впливом на їхню роботу. Щоб збільшити мотивацію та пов’язати іiі з RCJ, що тягне за собою взаємодію та фокус на колегах, було окреслено роль просоціальних мотивів управління та враження як граничні умови: Перша стосується схильності працівників піклуватися про потреби та добробут, будучи колегами [2], тоді як остання посилається на тенденції працівників створювати сприятливий образ в очах колег. Прийняття кута мотивації для розуміння наслідків RJC є важливим, оскільки RJC є ризикованим починанням, може виснажувати (або збагачувати) особисті ресурси працівників на роботі, може викликати негативні реакції у колег [13] і таким чином потребує стійкої енергії.

Щоб вивчити дослідницькі питання, був прийнятий дизайн щотижневого щоденника, що оцінюється керівником, що є перевагою цього дослідження. Теоретична та емпірична робота з розробки робочих місць переважно переважає підхідною ознакою, досліджуючи відмінності між особами щодо ролі крафтової роботи в результатах працівників [6]. Теоретично розробка робочих місць, як правило, розглядається як статичні, одноразові зміни, які вносять працівники на свою роботу [8]. Емпіричне дослідження вивчило відносно статичне сприйняття крафтів як стабільної змінної, що відрізняє одну людину від іншої [12]. Однак останні дослідження з розробки робочих місць свідчать про те, що розробка робочих місць працівників та пов'язані з цим результати роботи співробітників динамічні, можуть коливатися протягом тижнів, оскільки фактори, що визначають їх, також змінюються від тижня до тижня [14]. У контексті дослідження співробітники, ймовірно, беруть участь у RJC, які трапляються рідше, ніж дні тижня [14]. 3 цих причин; було перевірено гіпотези, використовуючи дизайн щоденника [15] та отримавши дані 3 багатьох джерел, зібрані від співробітників, що працюють в центрі інформації та їхніх прямих керівників. Вживаючи дизайн щоденника, вивчається RJC в його організаційному контексті, а також рівень, яким він виявляється, лежачи в основі його динамічної природи [7]. Таким чином, було розширено останні щотижневі дослідження в рамках особистості, які почали досліджувати соціальну сторону виходу на роботу за допомогою динамічного підходу.

Для перевірки наших гіпотез було використано багаторівневий дизайн щоденника з різними джерелами (понад сім тижнів) [15]. Зразок складався з штатних працівників, які були зараховані в програму Ехеcutive MBA. Перед початком дослідження всі потенційні учасники, що навчалися в цьому модулі $(\mathrm{N}=123)$, були поінформовані про цілі дослідження. Їх запевнили, що участь у дослідженні не пов'язана ні з їхніми навчальними досягненнями в школі, ні 3 потребою в курсі. Зрештою, 67 студентів вирішили добровільно брати участь щотижня протягом семи тижнів. Через відсутні дані ми використали опитування 43 працівників (64\% участі).

До початку дослідження учасники завершили опитування ознак, яке включало вимірювання демографічних показників, контрольних змінних та мотивів ознак. Через тиждень після початку ми почали збирати дані на рівні щотижня. Учасників попросили заповнити щотижневі опитування в понеділок за попередній тиждень (з понеділка по п’ятницю) і попросили надати їх керівникам запечатаний конверт із копією форми опитування менеджерів. Керівники оцінювали результати роботи та конструктивну поведінку своїх підлеглих і просили повторно закріпити конверти та повернути їх своїм підлеглим. Наступного тижня кожен фокусний співробітник повернув два опитування першому автору дослідження. Вони вказали імена керівників, які заповнили опитування для них, i дані узгодили, використовуючи імена керівників та координаторів працівників. Щоб переконатися, що саме наглядові органи заповнювали опитування від імені своїх підлеглих, випадковим чином було надіслано електронну пошту та зателефоновано до нагляду, використовуючи загальнодоступну контактну інформацію. Підсумковий зразок складався з 43 підлеглих ( $\mathrm{N}=43 ; 301$ точка даних). Опитування було переведено на турецьку мову за допомогою запропонованих процедур.

Було проведено аналіз потужності [16] для визначення та визначення розміру вибірки на рівні 2. Результати (процедура та детальні результати можна отримати від першого автора на запит), з метою досягнення 95\% довірчого інтервалу. Крім того, зразок відповідав дослідженням, які пропонують мінімальний рівень для досягнення значущих та значних розмірів ефекту [17]. Нарешті, було порівняно розмір вибірки рівня 2 із відповідними дослідженнями. Хоча існують дослідження, в яких використовували розмір вибірки рівня 2 нижче 42, є також дослідження, які використовують розмір вибірки рівня 2 вище 42 [18].

Як один з небагатьох курсів з вищої кваліфікації МВА, що викладається англійською мовою, ця програма має вимогливі вимоги до прийому щодо навчальних досягнень та попереднього досвіду. Після закінчення навчання відслідковується кар'єрний розвиток та підвищення кваліфікації студентів. Таким чином, це був відповідний зразок, за допомогою якого можна спостерігати за поведінкою, що займається роботою. Середній вік учасників становив 31,60 років (SD = 6,03 років), а 44 відсотки - чоловіки. В середньому вони працювали зі своєю нинішньою компанією 3,23 року $(\mathrm{SD}=1,64$ року).

Учасники працювали на керівних посадах у різних галузях промисловості: 44 відсотки працювали у сфері фінансових послуг, 28 відсотків у виробництві та 18 відсотків у консалтингу, тоді як дев'ять відсотків повідомили про роботу в “іншій” категорії (включаючи самостійно започатковані підприємства, вища освіта та готельного господарства). У їхніх компаніях 18 відсотків працювали у фінансах, 18 відсотків у продажах, 18 відсотків у розвитку бізнесу, 16 відсотків у маркетингу та 28 відсотків в управлінні відносинами 3 клієнтами.

Таким чином, актуальність та теоретичне обгрунтування теми дослідження повністю сформовано внаслідок чого були розроблені прикладні аспекти для подальшого формування. 


\section{Практичні аспекти}

Після виконання всіх базових етапів програмування отримуємо готовий програмний продукт, який вирішує поставлені завдання.

Вперше заходячи в додаток, користувач потрапляє на головну сторінку. Потрібно додати контейнер в якому будуть знаходиться безліч компонентів:

$<$ View

style $=\{$ [styles.container, isActiveDarkTheme \&\& \{ backgroundColor: '\#343434' $\}]\}>$

Для того щоб продемонструвати список завдань, потрібно додати ScrollView, завдяки йому можна генерувати список компонентів і їх можна буде скролити. Перед виведенням інформації потрібно перевірити чи $є$ у користувача створені завдання:

\{list.length $>=1$ ?

$<$ ScrollView style $=\{$ styles.scrollView $\}$ showsVerticalScrollindicator $=\{$ false $\}>$

$<$ View style $=\{$ styles.marginTop $\} />$

$\{$ list.map $($ (item, index $)=>$

Даний компонент є завданням, в нього ми передаємо всі потрібні дані для виведення, які вводимо всередині компонента:

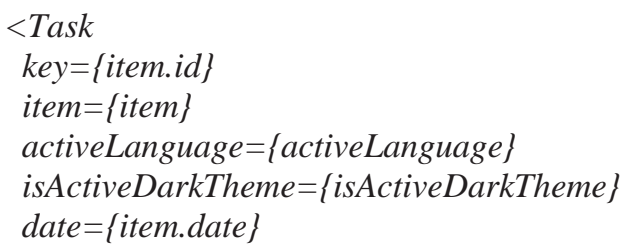

Тут виконується умови перевірки перший чи це індекс і відрізняється у нього дата від попереднього об'єкта, якщо в обох випадках ми отримуємо позитивний результат, то виводимо дату для зручності користувача:

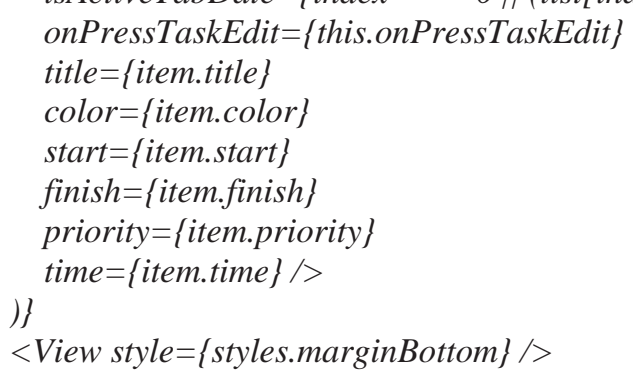

Далі якщо у користувача немає завдань, то умова демонструє інший компонент, в котрому є повідомлення користувачу про те, що потрібно додати завдання, щоб задача з'явилася в списку:

$<$ View style $=\{$ styles.nullWrapper $\}>$

$<$ Text style $=\{$ [styles.nullText, isActiveDarkTheme $\& \&\{$ color: '\#fff' $\}]\}>H i$, add a new task! :) $</$ Text $>$

$</$ View $>$

\}

Далі демонструється компонент кнопки додавання нового завдання, за допомогою неї можна викликати модальне вікно створення завдання:

$<$ TouchableOpacity

style $=\{$ [styles.plusWrapper, list.length $===0 \& \&\{$

Нижче представлена анімація, яка робить ефект вібрації кнопки, якщо у користувача ще немає завдань. Це зроблено для того, щоб він звернув увагу і додав свою першу задачу:

transform: [\{

rotate: this.animatedValue.interpolate(\{

inputRange: [-1, 1], outputRange: ['-0.1rad', '0.1rad']

\})

\}]

\}]\}

onPress $=\{$ this.onPressPlus $\}$

$>$

$<$ Image style $=\{$ styles.plus $\}$ source $=\{$ require('../../Assets/plus.png') $\} />$

$</$ TouchableOpacity $>$

Тут знаходиться компонент навігації за додатком, це меню знаходиться внизу додатки для зручності. Має в собі 3 кнопки: головна сторінка, голосовий асистент і сторінка налаштувань:

$<$ BottomMenu 


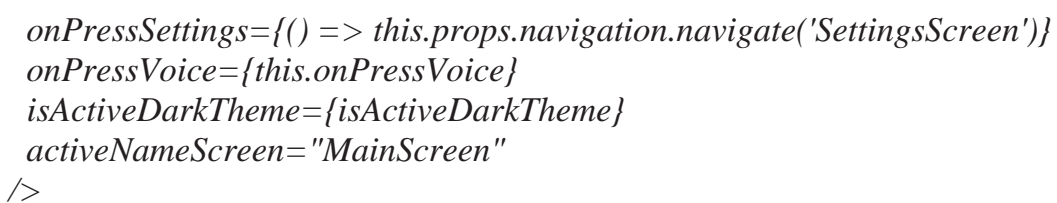

Нижче представлений компонент служить для створення завдань, саме він викликає після натискання на кнопку, яка описувалася раніше. У нього ми передаємо параметри активний він зараз чи ні і всі інші потрібні параметри:

$<$ CreateTaskModal

onPressCloseCreateTaskModal $=\{$ this.onPressCloseCreateTaskModal $\}$

titleSpeechForModal $=\{$ titleSpeechForModal $\}$

isActiveDarkTheme $=\{$ isActiveDarkTheme $\}$

activeLanguage $=\{$ activeLanguage $\}$

is Active $=\{$ isActiveCreateTaskModal $\}$

$>$

Тут викликається практично подібний компонент як і попередній, він створений для редагування вже існуючих завдань:

\section{$<$ EditTaskModal}

onPressCloseEditTaskModal $=\{$ this.onPressCloseEditTaskModal $\}$

isActiveDarkTheme $=\{$ isActiveDarkTheme $\}$

activeLanguage $=\{$ activeLanguage $\}$

item $=\{$ activeItem $\}$

isActive $=\{$ isActiveEditTaskModal $\}$

I>

Даний компонент створений для демонстрації користувачеві, що зараз працює голосовий асистент:

$<$ SpeechModal

text $=\{$ this.speechText $\}$

is Active $=\{$ isActiveSpeech $\}$

isActiveDarkTheme $=\{$ isActiveDarkTheme $\}$

$>$

$</$ View $>$

Зараз буде наведено приклад роботи голосового помічника. Після натискання на кнопку голосового асистента в меню буде викликана функція:

onPressVoice $=()=>\{$

const $\{$ activeLanguage $\}=$ this.state;

Йде перевірка яка мова зараз у користувача в інтерфейсі, щоб подабрать правильний реєстратор мови:

Voice.start(activeLanguage $===$ 'English' ? 'en-US' : 'uk-UA');

this.speechText = ";

Міняємо параметр і говоримо всьому класу, що зараз почне працювати голосовий асистент:

this.setState( $\{$ isActiveSpeech: true \}); \}

Для того, щоб стежити за словами користувача ми повинні створити функцію слухач і передати їй інформацію всередині цього класу:

Voice.onSpeechResults = this.onSpeechResultsHandler.bind(this);

А ось і сам слухач, в ньому передається дані в яких знаходяться слова користувача:

onSpeechResultsHandler(event) \{

Тут чиститься тайм аут, це робиться з метою того, щоб очистити діюче завершення часу очікування. Грубо кажучи, ми говоримо що прийшли нові слова і потрібно продовжувати роботу:

clearTimeout(this.timeout);

Передаємо перемінної нові пропозицію:

this.speechText = event.value[0].toLowerCase();

А ось і сам тайм аут, який завершує роботу асистента якщо той перестав говорити. Через одну секунду і п'ять мілісекунд він зупиняли слухач і перейде в функцію з усіма командами програми, які були задані і в разі успіху він виконає дію, яку задав користувач:

this.timeout $=$ setTimeout $(()=>\{$

this.speechDo();

Voice.cancel();

\}, 1500);

\}

Нижче представлена робота з базою даних. За допомогою даного методу ми викликаємо редагування потрібної завдання:

export const editTask $=($ item $)=>\{$

return new Promise $($ (resolve $)=>\{$ 
Відкриваємо транзакцію в якій будемо звертатися до бази даних:

Realm.open(\{schema: [TaskSchema]\}) then $($ realm $=>\{$

Шукаємо в базі потрібну задачу завдяки тому, що у нас $є$ айди завдання: const find $=$ realm.objects('Task').filtered('id $==\$ 0$ ', item.id);

Змінюємо поточні параметри на нові, які ми передали: realm.write $(()=>\{$

find[0].title = item.title;

find [0].color = item.color;

find [0].time = item.time;

find[0].start = item.start;

find [0].date = item.date;

find[0].datetime = item.datetime;

find[0].finish = item.finish;

f);

find [0].priority = item. priority;

Передаємо позитивний результат назад:

resolve(true);

\})

У разі помилки виводимо інформацію в логах, іiі може подивитися тільки програміст під час налагодження програми:

$\operatorname{catch}(($ error $)=>\{$

console.log(error);

resolve(false);

\});

\}$) ;$

\}

Для того щоб впровадити систему, потрібно задовольнити деякі потреби, задля роботи додатку. Є два способи запуску програми:

1. За допомогою справжнього телефону;

2. За допомогою емулятора телефону.

Даний способи підходять як для OC Android так і для iOS. Єдина різниця цих операційних систем в тому що для OC Android створюється *.apk файл і далі він встановлюється на телефон як звичайна програма і готовий до використання.

Для операційної системи $\mathrm{IOS}$ все трохи складніше. Для того, щоб будь-який користувач міг використовувати додаток його потрібно викласти на App Store, даний додаток $є$ на всіх девайсах від Аррlе. Але також $є$ можливість викласти його в спеціальний додаток для альфа і бета тестування - Test Flight. Для того щоб була можливість завантажити додаток до себе на телефон за допомогою Test Flight, розробник або власник додатка повинен скинути запрошення на пошту з кодом верифікації, після чого можна спокійно завантажити собі програму і починати 3 ним працювати.

Після установки програми ми побачимо головну сторінку. Варто зауважити, що додаток працює на OC Android i iOS абсолютно однаково, що є великим плюсом, оскільки ніхто нічим не обмежений, як буває дуже часто у багатьох додатків. Так ось після відкриття додатка ми побачимо головну сторінку, для прикладу будемо розглядати додатки на емуляторі iPhone 11 з IOC 13.2.2.

Після того як ми відкрили головну сторінку, ми бачимо пропозицію про додавання нового завдання і кнопку зі знаком плюсом, який робить анімацію вібрації, для того щоб користувач звернув увагу. Після натискання відкривається модальне вікно створення завдання.

Після створення завдання закривається модальне вікно і користувач може побачити своє завдання.

Для того щоб редагувати завдання потрібно натиснути на іконку праворуч внизу на завданню, або можна натиснути на голосового асистента внизу в меню і можна сказати команду "редагувати завдання" і сказати назву завдання. 


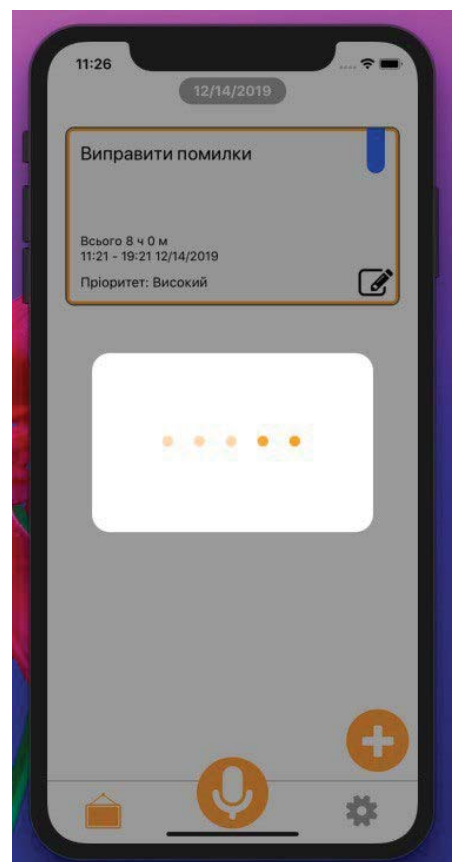

Рис 1 - Голосовий помічник.

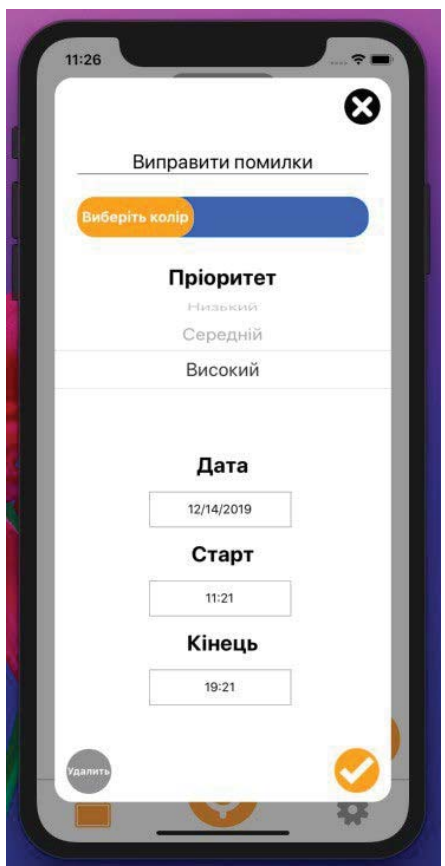

Рис. 2 - Модальне вікно редагування завдання.

Після того як користувач озвучить одну з дозволених команд (всього їх 11 українською мовою і 11 англійською мовою), він виконав потрібну дію, в даній ситуації він відкриє потрібну задачу і ії можна буде редагувати (рисунок 2).

У додатку $є$ ще одна сторінка, вона служить для налаштування програми. Можна перейти за допомогою голосового помічника, або натиснути на правою іконку в нижньому меню і відкриється сторінка налаштувань.

На даній сторінці можна заповнити таку інформацію як ім'я, електронна пошта і фотографія користувача. Також $є$ налаштування мови, на даний момент підтримується такі мови як українська та англійська. Ще є темна тема додатку, вона служить для економії заряду телефону і спрощує перегляд завдань вночі, оскільки темна тема не кидається сильно в очі і менше псує зір. Застосуємо всі зміни і подивимося як виглядає темна тема і англійська мова у додатку, змінюється все швидко і без очікувань і закриття програми.

Повернемося назад на головну сторінку і подивимося на змінений дизайн, також вже 3 доданими даними для зручності і розуміння як виглядає програма.

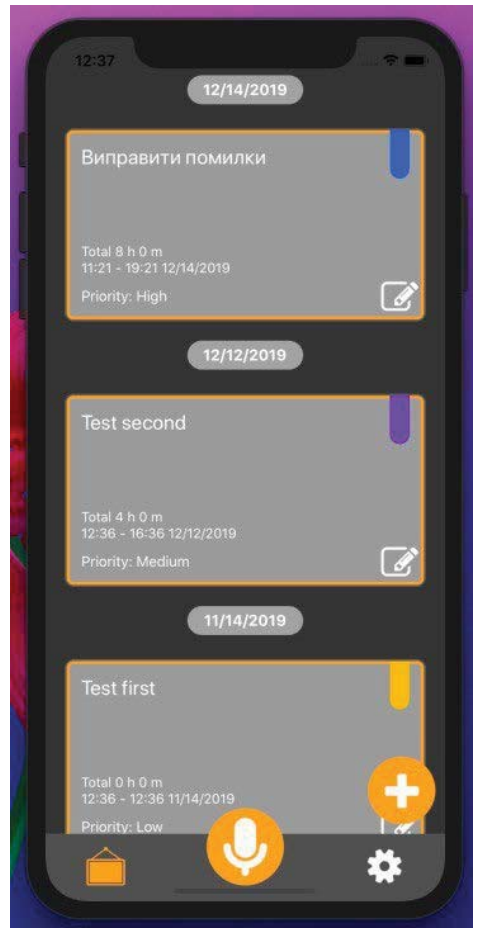

Рис. 3. - Головна сторінка $з$ темною темою.

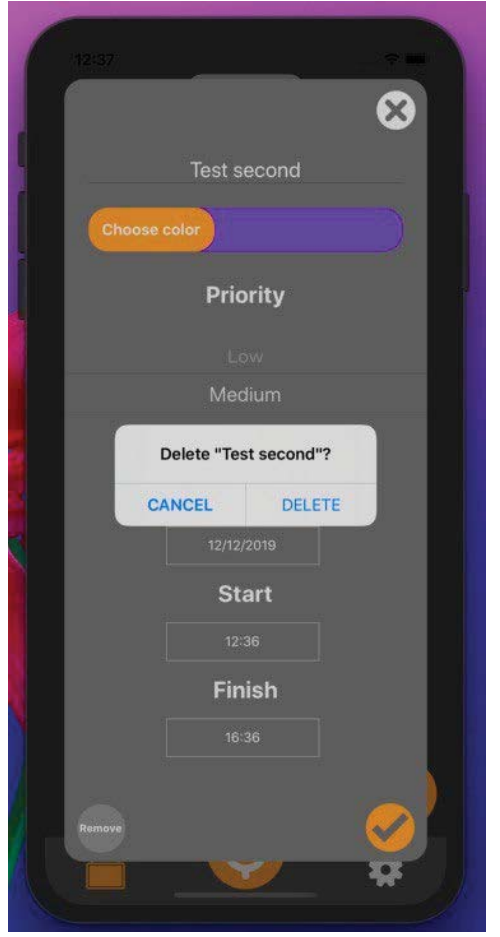

Рис. 4. - Модальне вікно підтвердження дії. 
Крім того, в програмі є можливість видаляти раніше створені завдання, для цього потрібно знайти потрібну задачу і натиснути на кнопку редагування і натиснути внизу на кнопку видалення, після чого з'явиться модальне вікно 3 підтвердженням даної дій (рисунок 4). Це робиться з метою того, щоб юзер часом не натиснув на кнопку і не пішло виконуватися завдання.

У додатку існує можливість додати колір до задачі, це допомагає відрізнити потрібну задачу якнайшвидше, що збільшує комфортність роботи з додатком.

\section{Висновки}

Основна особливість програми, яка виділяє їі серед всіх - голосовий асистент. Завдяки їй можна прискорити безліч процесів. У загальній сумі голосових команд 22 (11 команд українською мовою і 11 команд англійською мовою).

Повний список команд:

1. Створити завдання - створює нову задачу, також можна сказати відразу назву і воно вже буде 3 необхідною назвою;

2. Редагувати завдання - відкриває модальне вікно з потрібною задачкою, для того щоб він ії знайшов потрібно сказати назву;

3. Знайти завдання - знаходить потрібну задачу, потрібно сказати також назву;

4. Змінити ім'я на - змінює ім'я профілю, потрібно сказати на яке ім'я і він сам підставить потрібний текст;

5. Змінити електронну пошту на - змінює електронну пошту, потрібно сказати на яку пошту ви хочете поміняти;

6. Включити темну тему - включає темну тему додатки;

7. Вимкнути темну тему - вимикає темну тему додатки;

8. Змінити мову інтерфейсу - змінює інтерфейс програми;

9. Змінити фотографію - відкриває модальне вікно за допомогою якого можна поміняти фотографію профілю;

10. Відкрити параметри - відкриває сторінку налаштувань програми;

11. Відкрити головну сторінку - відкриває головну сторінку додатка.

\section{References}

[1]. Grant AM and Parker SK (2009) Redesigning work design theories: The rise of relational and proactive perspectives. Academy of Management Annals 3(1): 317-375. https://doi.org/10.5465/19416520903047327

[2]. Grant AM (2007) Relational job design and the motivation to make a prosocial difference. Academy of Management Review 32(2): 393-417. https://doi.org/10.5465/amr.2007.24351328

[3]. Morgeson FP and Campion MA (2003) Work design. In: Borman W, Klimoski R and Ilgen D (eds) Handbook of Psychology, Volume 12: Industrial and Organizational Psychology. New York, NY: John Wiley, $423-452$. https://doi.org/10.1002/0471264385.wei1217

[4]. Latham GP and Pinder CC (2005) Work motivation theory and research at the dawn of the twenty-first century. Annual Review of Psychology 56: 495-516. https://doi.org/10.1146/annurev.psych.55.090902.142105

[5]. Laurence GA (2010) Workaholism and expansion and contraction oriented job crafting: The moderating effects of individual and contextual factors. Unpublished doctoral dissertation, Syracuse University, Syracuse, NY.

[6]. Rudolph CW, Katz IM, Lavigne KN and Zacher H (2017) Job crafting: A meta-analysis of relationships with individual differences, job characteristics, and work outcomes. Journal of Vocational Behavior 102: 112-138. https://doi.org/10.1016/j.jvb.2017.05.008

[7]. Wang HJ, Demerouti E and Bakker AB (2016) A review of job crafting research: The role of leader behaviors in cultivating successful job crafters. In: Parker SK and Bindl UK (eds) Proactivity at Work. London, UK: Routledge, Ch.4.

[8]. Wrzesniewski A and Dutton JE (2001) Crafting a job: Revisioning employees as active crafters of their work. Academy of Management Review 26(2): 179-201. https://doi.org/10.2307/259118. https://doi.org/10.5465/amr.2001.4378011

[9]. Van den Broeck A, Vansteenkiste M, De Witte H and Lens W (2008) Explaining the relationships between job characteristics, burnout and engagement: The role of basic psychological need satisfaction. Work \& Stress 22(3): 277294. https://doi.org/10.1080/02678370802393672

[10]. Bruning PF and Campion MA (2017) A role-resource approach-avoidance model of job crafting: A multi-method integration and extension of job crafting theory. Academy of Management Journal. https://doi.org/10.5465/amj.2015.0604

[11]. Ng TWH and Feldman DC (2013) Changes in perceived supervisor embeddedness: Effects on employees' embeddedness, organizational trust, and voice behavior. Personnel Psychology 66: 645-685. https://doi.org/10.1111/peps.12025

[12]. Lu C Wang H Lu J Du D and Bakker AB (2014) Does work engagement increase person-job fit? The role of job crafting and job insecurity. Journal of Vocational Behavior 84(2): 142-152. https://doi.org/10.1016/j.jvb.2013.12.004

[13]. Demerouti E, Bakker AB and Gevers J (2015b) Job crafting and extra-role behavior: The role of work engagement and flourishing. Journal of Vocational Behavior 91: 87-96. https://doi.org/10.1016/j.jvb.2015.09.001

[14]. Petrou P, Bakker AB and Van den Heuvel M (2017) Weekly job crafting and leisure crafting: Implications for meaning-making and work engagement. Journal of Occupational and Organizational Psychology 90(2): 129-152. https://doi.org/10.1111/joop.12160 
[15]. Bolger and Laurenceau (2013). Intensive Longitudinal Methods: An Introduction to Diary and Experience Sampling Research. New York: Guilford.

[16]. Ellis PD (2010) The Essential Guide to Effect Sizes: An Introduction to Statistical Power, MetaAnalysis and the Interpretation of Research Results. Cambridge, UK: Cambridge University Press.

[17]. Scherbaum CA and Ferreter JM (2009) Estimating statistical power and required sample sizes for organizational research using multilevel modeling. Organizational Research Methods 12(2): 347-367. https://doi.org/10.1177/1094428107308906

[18]. Breevaart K, Bakker AB, Demerouti E and Derks D (2016) Who takes the lead? A multi-source diary study on leadership, work engagement, and job performance. Journal of Organizational Behavior 37(3): 309-32. https://doi.org/10.1002/job.2041

\section{THE USE OF CONTROL THEORY METHODS IN TRAINING NEURAL NETWORKS ON THE EXAMPLE OF TEETH RECOGNITION ON PANORAMIC X-RAY IMAGES}

\section{Smorodin A.}

Odessa Polytechnic State University, Odessa, Ukraine

ORCID: 0000-0002-3370-3197

E-mail: andrey.v.smorodin@opu.ua

Copyright (C 2021 by author and the journal “Automation of technological and business - processes”.

This work is licensed under the Creative Commons Attribution International License (CC BY).

http://creativecommons.org/licanses/by/4.0

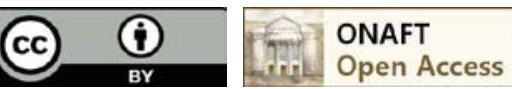

DOI:

Анотація. У статті досліджено модифікацію стохастичного градієнтного спуску (SGD) на основі раніше розробленої теорії стабілізації дискретних ичклів динамічної системи. Співвідношення між стабілізацією циклів у дискретних динамічних системах та знаходженням екстремальних точок дозволило застосувати нові методи управління для прискорення градієнтного спуску при наближенні до локальних мінімумів. Градієнтний спуск часто використовується для навчання глибоких нейронних мереж нарівні $з$ іншими ітераційними методами. Експериментували з двома градієнтами SGD та Адам, було проведено порівняльні експерименти. Усі експерименти проводилися під час вирішення практичної задачі розпізнавання зубів на 2-D панорамних знімках. Мережеве навчання показало, щуо новий метод перевершує SGD за його можливостями, а щзо стосується обраних параметрів, то він наближається до можливостей Адам, щчо $є$ “найсучаснішим” методом. Таким чином, показана практична корисність використання теорії управління у навчанні глибоких нейронних мереж та можливість розширення ії придатності у процесі створення нових алгоритмів у цій важливій галузі.

Abstract. The article investigated a modification of stochastic gradient descent (SGD), based on the previously developed stabilization theory of discrete dynamical system cycles. Relation between stabilization of cycles in discrete dynamical systems and finding extremum points allowed us to apply new control methods to accelerate gradient descent when approaching local minima. Gradient descent is often used in training deep neural networks on a par with other iterative methods. Two gradient SGD and Adam were experimented, and we conducted comparative experiments. All experiments were conducted during solving a practical problem of teeth recognition on 2-D panoramic images. Network training showed that the new method outperforms the SGD in its capabilities and as for parameters chosen it approaches the capabilities of Adam, which is a "state of the art" method. Thus, practical utility of using control theory in the training of deep neural networks and possibility of expanding its applicability in the process of creating new algorithms in this important field are shown.

Ключові слова: методи теорії управління, дискретна динамічна система, стабілізація циклів, нейронна мережа, навчання

Keywords: control theory methods, discrete dynamical systems, stabilization of cycles, neural networks, training 